\title{
Cadmium affects microtubule organization and post-translational modifications of tubulin in seedlings of soybean (Glycine max L.)
}

\author{
Jarosław Gzyl*, Jagna Chmielowska-Bąk, Roman Przymusiński and Edward A. Gwóźdź \\ Department of Plant Ecophysiology, Institute of Experimental Biology, Faculty of Biology, Adam Mickiewicz University, \\ Poznań, Poland
}

Cadmium (Cd) is a non-essential heavy metal, toxic to all living organisms. The microtubule (MT) cytoskeleton appears to be one of the main targets of $\mathrm{Cd}$ action. In this study we present, with the use of various immunological approaches, the effect of $\mathrm{Cd}$ at moderate $(85 \mu \mathrm{M})$ and high $(170 \mu \mathrm{M})$ concentrations on the structure and functioning of the MT cytoskeleton in the root cells of soybean seedlings. As the result of

OPEN ACCESS

Edited by:

Mohammad Anwar Hossain, Bangladesh Agricultural University,

Bangladesh

Reviewed by:

Eleftherios P. Eleftheriou, Aristotle University of Thessaloniki,

Greece

Zhongxiong Lai,

Fujian Agriculture and Forestry

University, China

*Correspondence:

Jarosław Gzyl

jarekgzy|@yahoo.com

Specialty section:

This article was submitted to

Crop Science and Horticulture,

a section of the journal

Frontiers in Plant Science

Received: 09 July 2015 Accepted: 15 October 2015 Published: 06 November 2015

Citation:

Gzyl J, Chmielowska-Bakk J,

Przymusiński R and Gwóźdź EA (2015) Cadmium affects microtubule organization and post-translational modifications of tubulin in seedlings

of soybean (Glycine max L.).

Front. Plant Sci. 6:937.

doi: 10.3389/fpls.2015.00937 heavy metal action, root growth was significantly diminished and was accompanied by a reduction in mitotic activity and disturbance in the structure of the MT arrays, including randomization of the cortical MT arrangement, distorted mitotic arrays and complete depolymerization of the MTs. Biochemical analysis revealed decreased levels of various $\alpha$ - and $\beta$-tubulin isoforms with a parallel down-regulation of most examined $\alpha$-tubulin genes. Simultaneously, Cd treatment led to differentiated changes in the level of tubulin post-translational modifications, including tyrosination, detyrosination, acetylation, and polyglutamylation. Decreased tyrosination and polyglutamylation of particular tubulin isoforms accompanied by increase in the level of specific detyrosinated and acetylated isoforms implies augmented stability and reduced turnover of the MTs during stress conditions. Taken together, the obtained results indicate the significant impact of $\mathrm{Cd}$ on gene expression levels and subsequent post-translational processing of tubulin, which may be related to the impairment of MT cytoskeleton functioning in root cells.

Keywords: root, cadmium, microtubule cytoskeleton, immunocytochemistry, gene expression, immunoblotting, tubulin isoforms, post-translation modifications

\section{INTRODUCTION}

About 25,000 t of cadmium (Cd) per year is released into the environment, mainly through weathering of rocks, forest fires, volcanoes, and human activity, such as mining, agriculture, sewage processing, automobiles, and the metal industry (Dalcorso et al., 2013; Tran and Popova, 2013). Therefore, $\mathrm{Cd}$ has become a widespread non-essential heavy metal and one of the most toxic and dangerous environmental pollutants, with relative high mobility in the soil-plant system and ability to interfere with plant metabolism. Moreover, the metal accumulated in plant tissues might be introduced into the food chain, posing concerns for both animal and human nutrition. It is estimated that approximately $98 \%$ of ingested Cd comes from terrestrial foods (Tran and Popova, 2013). 
The roots are well established as a main site of $\mathrm{Cd}$ action leading to numerous disorders, including inhibition of root growth, alterations in their morphogenesis (Rascio et al., 2008), interference with mitotic process by induction of chromosome aberrations (Siddiqui et al., 2009) and cytoskeleton dysfunction (Fusconi et al., 2007). Although microtubule (MT) cytoskeleton seems to be one of the main targets of $\mathrm{Cd}$ action (Pribyl et al., 2005; Xu et al., 2009; Malea et al., 2013), its functioning under heavy metal stress is not well elucidated. The MTs play crucial functions in the growth and development of plants and contribute to the highly ordered organization of the most important cellular processes, including formation of mitotic spindle, the cell plate, cell growth and elongation or intracellular transport and cell wall deposition (Horio and Murata, 2014). During the cell cycle, plant MTs are assembled into four distinct arrays: the interphase cortical MTs, pre-prophase band, mitotic spindle and phragmoplast. From a structural point of view, most MTs consist of 13 protofilaments which form a hollow cylinder. The protofilaments are polymers of heterodimers containing one $\alpha$-tubulin and one $\beta$-tubulin subunit, each with a molecular weight of about $50 \mathrm{kDa}$ (Parrotta et al., 2014). In spite of their quite simple structure, MTs can be precisely regulated throughout the cell cycle or cell differentiation to carry out diverse but specific cellular functions. The MT cytoskeleton may be controlled at a few different levels, and the final effect of MTs functioning is resultant of the expression of distinct tubulin genes (isotypes), tubulin post-translational modifications (PTMs) and a repertoire of MT-associated proteins (MAPs). The latter can regulate both the dynamics of MTs and their association with other cellular components as nonmotor MAPs and MAPs with motor ability (Hamada, 2007). However, the primary level of tubulin heterogeneity is dependent on the differential expression of isotypes, which is probably regulated according to the specific developmental stage of a plant, the specific tissue or organ, as well as various internal and external stimuli (Oakley et al., 2007; Radchuk et al., 2007).

Plants have evolved a large heterogeneity in the number of $\alpha$ - and $\beta$-tubulins genes, and different plants possess diverse sets of tubulin genes (Parrotta et al., 2014). Presynthesised tubulin proteins can be next post-translationally modified to obtain differentiated subpopulations of MTs and to increase the heterogeneity of tubulin isoforms. The PTMs of tubulin are evolutionarily conserved and highly dynamic processes, therefore it is very likely that they play crucial functions in the eukaryotic cells (Parrotta et al., 2014). So far, several PTMs of tubulin have been recognized in plants, including tyrosination, detyrosination, acetylation (Smertenko et al., 1997b; Gilmer et al., 1999a,b; Nakagawa et al., 2013), phosphorylation (Blume et al., 2008; Ban et al., 2013), polyglutamylation (Wang et al., 2004), and transamidation (Del Duca et al., 2009). Most PTMs take place at the C-terminal tails of both tubulin subunits, and their level plays an essential role in the properties of MTs themselves as well as their interaction with associated proteins. Futhermore, PTMs may function individually and/or in combination to recruit specific protein complexes and thus govern the spatial and temporal regulation of the MT cytoskeleton during the cell cycle.
Tyrosination is a quite common and predominant modification because tubulins are normally synthesized with tyrosine as the last C-terminal amino acid. The enzymatic removal of C-terminal tyrosine by tubulin-specific carboxypeptidase generates detyrosinated tubulin (Glu-tubulin), which in turn can be subject to the opposite process of tyrosination with the use of specific enzyme tubulin tyrosine ligase (MacRae, 1997). It is assumed that the process of tubulin detyrosination is associated with increased MT stability, which is considered to protect MTs from depolymerisation (Peris et al., 2009). In acetylated tubulin isoforms, the acetyl group is attached to the $\alpha$-amino group of lysine 40 , and this PTM is detected in most cells in stable MTs (Piperno et al., 1987), but the exact function and significance of acetylated MTs in plants remain to be elucidated. Polyglutamylation is an abundant modification, which leads to the addition of glutamate side chains of variable length to the C-terminal tails of either $\alpha$ - or $\beta$-tubulin. In opposition to tyrosination, it is not processed on soluble tubulin subunits, but takes place, like detyrosination, on MTs (Parrotta et al., 2014).

Despite the importance of PTMs to proper MTs functioning, limited information is available concerning environmental stresses, including heavy metals treatment (Eleftheriou et al., 2013, 2015). In this report we documented the impact of $\mathrm{Cd}$ in moderate and high concentrations on the PTMs levels in the root tips of soybean. To our best knowledge this is the first report showing that $\mathrm{Cd}$ stress causes changes in the population of tyrosinated, detyrosinated, acetylated, and polyglutamylated isoforms of tubulin in plant cells. The proteomic approach based on a set of specific antibodies implies increased stability of MT fibers under stress conditions. Additionally, immunocytochemistry and ultrastructural observations proved clear impact of Cd on MTs functioning.

\section{MATERIALS AND METHODS}

\section{Plant Material, Growth Conditions and Treatment Procedures}

Soybean seeds (Glycine max L. cv. Nawiko, kindly supplied by the Department of Genetics and Plant Breeding, University of Life Sciences, Poznań, Poland) were sterilized in 70\% ethanol for $5 \mathrm{~min}$ and in $20 \%$ Clorox (1\% sodium hypochlorite) for $10 \mathrm{~min}$, rinsed with distilled water and imbibed for $4 \mathrm{~h}$ in distilled water $\left(\mathrm{dH}_{2} \mathrm{O}\right)$. The seeds were then germinated for 2 days in plastic dishes lined with filter paper moistened with $\mathrm{dH}_{2} \mathrm{O}$. Seedlings with primary roots approximately $10 \mathrm{~mm}$ in length were transferred to Petri dishes (10 seedlings per dish) containing $4 \mathrm{ml}$ of $\mathrm{dH}_{2} \mathrm{O}$ (control) or aqueous solutions of $\mathrm{CdCl}_{2}{ }^{\mathrm{x}} 2.5 \mathrm{H}_{2} \mathrm{O}$ at different concentrations of the metal: 20,80,140, and $200 \mu \mathrm{M}$. The cultivation was carried out for $48 \mathrm{~h}$ in the dark at $22^{\circ} \mathrm{C}$. Based on root measurements and tolerance index calculations (Wilkins, 1957) two concentrations of Cd were determined. As a result, the $\mathrm{Cd}$ concentration at which root growth was limited by approximately 50\% (moderate stress conditions) was estimated at $85 \mu \mathrm{M}$ and the higher concentration of the metal was set at a value double the first (i.e., $170 \mu \mathrm{M}$ ). Both selected 
concentrations of $\mathrm{Cd}$ were used in all immunocytochemistry, molecular, biochemical and ultrastructure experiments.

\section{Immunocytochemical Localization of Tubulin}

Excised root fragments consisting of meristematic and elongation zones were immediately fixed for $3 \mathrm{~h}$ in a MT stabilizing buffer (MTSB: $50 \mathrm{mM}$ Pipes pH 7.0, $5 \mathrm{mM} \mathrm{MgSO}_{4}, 5 \mathrm{mM}$ EGTA) containing $4 \%$ freshly prepared paraformaldehyde. The fragments were then dehydrated in a series of ethanol solutions and embedded in Steedman's wax (Vitha et al., 2000). Samples were sectioned at a thickness of $7 \mu \mathrm{m}$ with a rotary microtome. After dewaxing, sections were treated overnight at $4^{\circ} \mathrm{C}$ with primary anti- $\alpha$-tubulin antibody (clone B-5-1-2, Sigma T5168) diluted 1:800 with PBS/1\% BSA. Subsequently, the sections were rinsed six times in $\mathrm{PBS}$ and then incubated at $37^{\circ} \mathrm{C}$ for $2 \mathrm{~h}$ with FITC-conjugated anti-mouse secondary antibody (Sigma F5262) diluted 1:400 with PBS/1\% BSA. After rinsing with PBS, the material was treated with a solution of propidium iodide (Sigma P4170) at a concentration of $1 \mu \mathrm{g} / \mathrm{ml}$ for $5 \mathrm{~min}$, rinsed again and mounted in antifadent solution (Citifluor Ltd) on glass slides. Sections were observed with an LSM 510 confocal microscope (Carl Zeiss, Jena, Germany). On average, five different roots were investigated.

\section{RNA Isolation and Reverse Transcription}

RNA isolation was carried out with the use of TriReagent (Sigma T9424) according to the manufacturer's instructions. For reverse transcription, $1 \mu \mathrm{g}$ RNA from each experimental variant was purified with the use of a Deoxyribonuclease Kit (Sigma AMPD1) and transcribed into cDNA using a ReverseTranscription Kit (Thermo Scientific Fermentas \#K1622). For real-time PCR reactions, the obtained cDNA was diluted five times.

\section{Measurements of Gene Expression}

The expression pattern was analyzed for seven genes encoding $\alpha$-tubulin. The gene sequences for tubulins were derived from the Phytozome database ${ }^{1}$, and the primers, listed in Table 1, were designed using primer3 software ${ }^{2}$. Real-time PCR reactions were performed on a Rotor-Gene 6000 Thermocycler (Corbett) in $20 \mu \mathrm{l}$ of reaction mixture containing $0.1 \mu \mathrm{M}$ of each primer, $1 \mu \mathrm{l}$ of diluted cDNA, $10 \mu \mathrm{l}$ of Power SYBR Green PCR Master

${ }^{1}$ http://www.phytozome.net

${ }^{2} \mathrm{http}: / /$ bioinfo.ut.ee/primer3-0.4.0
Mix (Applied Biosystems 4368577) and DEPC treated water. The real-time PCR reaction started with initial denaturation at $95^{\circ} \mathrm{C}$ for $5 \mathrm{~min}$, followed by 45 cycles consisting of $10 \mathrm{~s}$ at $95^{\circ} \mathrm{C}, 20 \mathrm{~s}$ at $45^{\circ} \mathrm{C}$ and $30 \mathrm{~s}$ at $72^{\circ} \mathrm{C}$ and finalized by denaturation at a temperature rising from 72 to $95^{\circ} \mathrm{C}$ by one degree every $5 \mathrm{~s}$. The $\mathrm{Ct}$ (cycle threshold) values were determined using a real-time PCR Miner (Zhao and Fernald, 2005), and relative gene expression was calculated according to the Pfaffl equation (Pfaffl, 2001) in relation to a reference gene - ubiquitin. Earlier studies showed that out of three potential tested reference genes (encoding ubiquitin, 18S rRNA, CDK-A), a ubiquitin gene exhibits the most stable expression in response to $\mathrm{Cd}$ and it has been used as reference gene in other studies concerning the impact of $\mathrm{Cd}$ on gene expression in soybean seedlings (Chmielowska-Bąk et al., 2013). Measurements were performed on samples from three independent experimental repetitions, with each sample consisting of a pool of at least 20 root tips $(6 \mathrm{~mm}$ long).

\section{Protein Extraction and 2D Gel Electrophoresis}

Excised root tips (6 mm long) were ground in liquid nitrogen to a fine powder, and proteins were precipitated with cold TCA$2 \mathrm{ME}$-acetone solution for at least $1 \mathrm{~h}$ at $-20^{\circ} \mathrm{C}$ according to the procedure of Méchin et al. (2007). Protein solubilization was carried out with the use of DeStreak Rehydratation Solution (GE HealthCare), supplemented with $20 \mathrm{mM}$ DTT and $0.2 \%$ Bio-Lyte buffer (BioRad). The protein concentration in the final samples was calculated using a commercial 2-D Quant Kit (GE HealthCare). The assay was executed according to the manufacturer's instruction using BSA as a standard, and each sample was analyzed at least three times. Finally, approximately $100 \mu \mathrm{g}$ of proteins were loaded onto $7 \mathrm{~cm}$ IPG strips with 4.7-5.9 $\mathrm{pH}$ gradient (BioRad). After overnight rehydratation, the strips were subjected to isoelectrofocusing (IEF) using Multiphor II (GE HealthCare) and a run was carried out as follows: $300 \mathrm{~V}$ $(2 \mathrm{~h}), 1500 \mathrm{~V}(1.5 \mathrm{~h})$, and $3500 \mathrm{~V}(8 \mathrm{~h})$. After IEF separation, the strips were stored at $-80^{\circ} \mathrm{C}$. Prior to SDS-PAGE, the strips were equilibrated $2 \times 15 \mathrm{~min}$ in an equilibration buffer $(50 \mathrm{mM}$ Tris-HCl, $\mathrm{pH} 8.8,6 \mathrm{M}$ urea, 30\% glycerol, $2 \%$ SDS, $0.002 \%$ bromophenol blue), first containing $65 \mathrm{mM} \mathrm{DTT}$, followed by an equilibration buffer with $135 \mathrm{mM}$ iodoacetamide. For the second dimension separation, the strips were applied to $10 \%$ precast polyacrylamide gels (BioRad) and run in a Mini-PROTEAN Tetra Cell (BioRad) at a constant current $(20 \mathrm{~mA}$ per gel) with a

TABLE 1 | The names of analyzed genes, their accession numbers in Phytozome database and the designed primers.

\begin{tabular}{llll}
\hline Gene name & Number in Phytozome databse & Left primer & Right primer \\
\hline Tuba1 & Glyma04g09350 & CCGAGTCTGGTGATGGAGAT & ACCACACATGTCCGACAGAA \\
Tuba2 & Glyma05g23230 & TGTCCTGCTCGACAATGAAG & GCACAAGGTTGTCTGGAAT \\
Tuba3 & Glyma06g09500 & CTCCGTTACTACGGGAAA & CAACATCGGTGTGTCAAGG \\
Tuba4 & Glyma08g12140 & TGAGGTGTCTCTCGCATTG & AGCCCCAACCTCCTCATAGT \\
Tuba5 & Glyma10g40150 & CCAACCTCAACCGTCTTT & GGAGGAAAGCATGAATGGA \\
Tuba6 & Glyma17g16831 & GTTGATGGTGCATTGAACG & ACAACATCACCCCGGTACAT \\
Tuba7 & Glyma20g27280 & ATTGAGCGTCCCACCTACAC & GGAGGAAAGCATGAAATGGA
\end{tabular}


Prestained Protein Ladder (Thermo Scientific). After separation, the proteins were blotted onto PVDF membranes.

\section{Antibodies}

The following antibodies were used in the detection of tubulin subunits: mouse monoclonal antibody B-5-1-2 (IgG1; Sigma T5168; diluted 1:5,000) was used to recognize an epitope located in the C-terminal end of the $\alpha$-tubulin isoforms; mouse monoclonal antibody TU-01 (IgG1; Novus Biologicals NB500-333; diluted 1:2,000) was directed against the N-terminal structural domain (epitope aa 65-97) of the $\alpha$-tubulin; and mouse monoclonal antibody TU-06 (IgM; Novus Biologicals NB120-7792; diluted 1:2,000) was directed against the N-terminal structural domain of $\beta$-tubulin and reacted with all charge variants of tubulin. Post-translationally modified tubulins were detected with the following antibodies: mouse monoclonal anti-tyrosine tubulin antibody TUB-1A2 (IgG3; Sigma T9028; diluted 1:5,000), which is non-reactive with cells that have been treated with pancreatic carboxypeptidase A under conditions which remove only the C-terminal tyrosine; monoclonal antiacetylated antibody 6-11B-1 (IgG2b; Sigma T6793; diluted $1: 2,000$ ), which recognizes an epitope located on the $\alpha 3$ isoform of Chlamydomonas axonemal $\alpha$-tubulin, within four residues of Lys-40 when this amino acid is acetylated; mouse monoclonal antibody GT335 (IgG1; Enzo Life Sciences ALX-804-885; diluted $1: 2,000)$, which recognizes most forms of polyglutamylated tubulin and other polyglutamylated proteins, independent of the length of the glutamate side chains; and, finally, rabbit polyclonal antibody against detyrosinated tubulin (IgG; Millipore AB3201; diluted 1:1,000), which specifically recognizes the detyrosinated form of the tubulin $\alpha$-chain (Glu tubulin). All used primary antibodies were highly specific against particular modifications of tubulins with an exception of GT335 which might recognize also other glutamylated proteins. Secondary anti-mouse or anti-rabbit antibodies conjugated with horseradish peroxidase (HRP) were provided by Agrisera (AS11 1772, diluted 1:20,000; AS09 602, diluted 1:30,000) or Santa Cruz Biotechnology (sc-2064, diluted $1: 10,000)$.

\section{Protein Blotting and Immunostaining}

Proteins were blotted onto PVDF membranes (Millipore) with the use of a TE22 Mighty Small Transfer Tank (Hoefer) in CAPS buffer (10 mM CAPS, $10 \%$ methanol, $0.01 \%$ SDS) for $1 \mathrm{~h}$ at a constant current of $1 \mathrm{~mA}$ per $1 \mathrm{~cm}^{2}$ of membrane $(70 \mathrm{~mA})$. The quality of transfer was evaluated by staining gels with CBB-R250 and checking the correct blotting of pre-stained molecular mass standards (Thermo Scientific). Membranes were stained with freshly prepared Ponceau S $[0.1 \%$ Ponceau S (w/v) in $5 \%$ acetic acid] to verify equal protein loading, and then blocked overnight with 5\% BSA in a TBST buffer $(10 \mathrm{mM}$ Tris $\mathrm{pH} 8.0,150 \mathrm{mM} \mathrm{NaCl}, 0.05 \%$ Tween 20) followed by incubation with different primary antibodies diluted in a TBST buffer. After five extensive washes in the TBST buffer, the membranes were incubated with the appropriate secondary antibodies and after extensively washing with the TBST buffer, the immunological reaction was visualized by the use of LumiLight Western Blotting Substrate according to the manufacturer's instructions (Roche). The chemiluminescent signal was captured on X-ray film (Fuji), and protein spots' level of intensity was analyzed by means of MultiGauge (release 2.2) Fuji software. The quantitative results were calculated as a ratio of pixel intensity values to area of spots, and the data were presented considering control or $170 \mu \mathrm{M} \mathrm{Cd}$ as a reference point (100\%). At least three independent blots from different experiments were analyzed. Some blots were stripped with a harsh stripping solution $(62.5 \mathrm{mM}$ Tris- $\mathrm{HCl}, \mathrm{pH}$ 6.8, 2\% SDS, $100 \mathrm{mM} \mathrm{2-}$ ME) for $30 \mathrm{~min}$ at $70^{\circ} \mathrm{C}$ and reprobed again to check cross reactivity with other antibodies against tubulin applied in the study.

\section{Transmission Electron Microscopy}

Excised root tip fragments (3 $\mathrm{mm}$ long) were immediately fixed in a mixture of $2 \%(\mathrm{v} / \mathrm{v})$ paraformaldehyde and $2 \%(\mathrm{v} / \mathrm{v})$ glutaraldehyde in $0.05 \mathrm{M}$ cacodylate buffer, $\mathrm{pH} 6.8$, for $3 \mathrm{~h}$ at room temperature. After three washes in a cacodylate buffer, 10 min per wash, cells were postfixed with $1 \% \mathrm{OsO}_{4}$ in the same buffer overnight at $4^{\circ} \mathrm{C}$. The roots were then dehydrated in a graded ethanol series with $1 \%$ uranyl acetate prestaining at the $70 \%$ alcohol step (overnight at room temperature). The material was embedded in LR white resin (Sigma 62662), and polymerized at $60^{\circ} \mathrm{C}$ for $24 \mathrm{~h}$. The roots were cut into ultrathin sections $(70 \mathrm{~nm})$ using a Reichert Ultracut S (Leica, Austria) microtome. Sections for TEM were stained with an aqueous solution of $9 \%$ uranyl acetate followed by $0.5 \%$ lead citrate. The ultrastructure of cells was examined under a Jem 1200 EX II (Jeol Co., Japan) transmission electron microscope at $80 \mathrm{kV}$. Sections of three different roots were prepared and viewed.

\section{RESULTS}

\section{Root Growth Under Cadmium Stress}

The effect of Cd on the root growth was examined $48 \mathrm{~h}$ after the incubation of seedlings in $\mathrm{Cd}$ solutions with $\mathrm{Cd}$ at concentrations of $20,80,140$, and $200 \mu \mathrm{M}$. It was found that Cd limited root growth proportionally to the concentration of the metal in the solution (Figure 1A). The measurements allowed tolerance index to be calculated for root growth. Determined concentrations for moderate stress $(85 \mu \mathrm{M})$ and high stress $(170 \mu \mathrm{M})$ conditions were tested again in terms of root growth inhibition and a significant and gradual reduction in root growth was observed (Figure 1B). In addition to significant root growth inhibition, $\mathrm{Cd}$ also altered the morphology of roots, which became brownish (Figure 1C) and more brittle than the control roots.

\section{Cadmium Effects on Microtubule Organization in Root Cells}

The double-label staining of longitudinal root tip sections with anti- $\alpha$-tubulin antibody and DNA-binding dye (propidium iodide) revealed differentiated MT signal intensity (green immunofluorescence) under $\mathrm{Cd}$ treatment (Figure 2). The most pronounced fluorescence was observed in sections of 

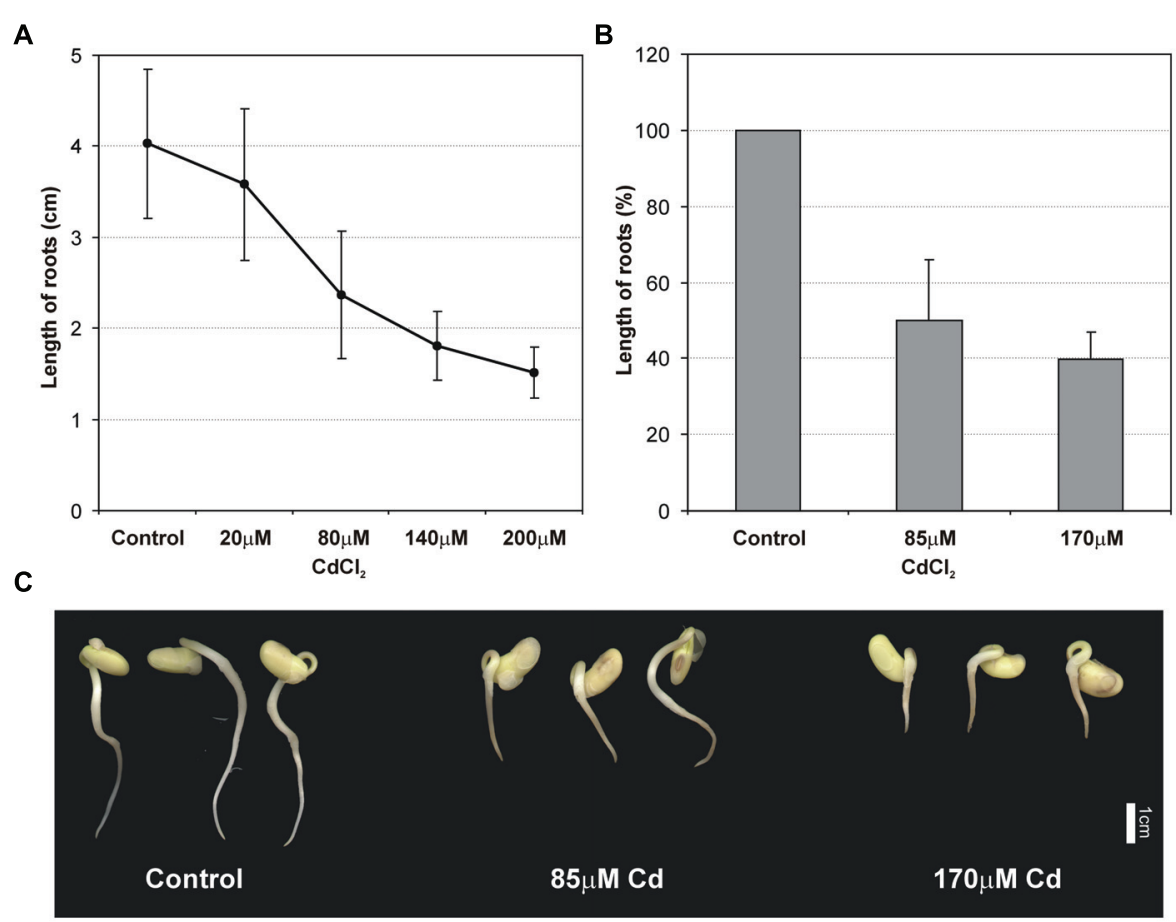

FIGURE 1 | Effect of different Cd concentrations on the primary root growth of 2 days old soybean seedlings (A). Effect of moderate (85 $\mu$ M Cd) and high $(170 \mu \mathrm{M}$ Cd) cadmium stress on root length $\mathbf{( B )}$ and morphology of seedlings $\mathbf{( C )}$. The results represent the mean with standard deviation of three independent experiments after $48 \mathrm{~h}$ treatment.

control roots (Figure 2A). At a moderate concentration of the metal $(85 \mu \mathrm{M})$, the main fluorescence signal was observed in procambium cells (Figure 2B), whereas at a high Cd treatment $(170 \mu \mathrm{M})$, a faint staining was observed limited mostly to the procambium area (Figure 2C). Moreover, higher magnification of the control sections revealed many cells at different stages of division (Figure 2D), while under moderate $\mathrm{Cd}$ stress a significant reduction in mitotic activity (approximately 60\%) was observed (Figure 2E). No cell divisions were observed in the root sections of seedlings treated with a high $\mathrm{Cd}$ concentration (Figure 2F). The highest magnification of control cells made it possible to observe a detailed picture of the stained MT cytoskeleton at different stages of the cell cycle, including cortical MTs (Figures 2G-I), preprophase band (Figure 3A) and perinuclear MTs (Figure 3B), mitotic spindle (Figure 3C) and phragmoplast (Figure 3D). The cortical MTs in control cells of soybean roots formed a fine, subtle and dense network orientated perpendicular to the long axis of the cells in the procambium and cortex area (Figure 2G). On the other hand, in the cells of seedlings treated with $\mathrm{Cd}$ the structure pattern of cortical MTs was significantly deformed in the cortex tissue, and included a decrease in the number of cortical MT bundles, randomization of the microtubular network, thickenings on individual MT fibers (dot-like staining) and discontinuous wavy MT bundles (Figure 2H). Finally, a complete disassembly and depolymerization of the MTs occurred, evidenced by short MT fragments and amorphous clusters of fluorescence signal, especially pronounced in the external cells of cortex tissue
(Figure 2I). In contrast to the cortex area, the procambium cells of Cd-treated seedlings showed no or much less evident changes in their MT structures. The dividing cells observed at a moderate concentration of $\mathrm{Cd}$ also displayed a distorted structure of the MT cytoskeleton, such as arrays without MT bunches (Figures 3E,H) or with MT fibers outside the main body of the array (Figures 3F,G). In control experiments, neither the primary antibody B-5-1-2, nor the FITC-conjugated secondary antibody alone gave any specific staining.

\section{Expression of Genes Encoding $\alpha$-tubulin}

Cadmium treatment also had detrimental effects on the expression of the vast majority of analyzed genes encoding $\alpha$-tubulin (Figure 4). A significant decrease (generally over 50\%) in the expression of all estimated genes was observed in moderate $(85 \mu \mathrm{M})$ and high $(170 \mu \mathrm{M}) \mathrm{Cd}$ treatments. A weak increase in expression of one gene Tuba3 was found at a high concentration of Cd compared to control seedlings. Moreover, in the case of three genes - Tub $\alpha 1, T u b \alpha 5$, and Tub $\alpha 7$ - the decrease in genes expression was more pronounced in response to moderate than to high Cd concentration.

\section{Accumulation of Tubulin Isoforms Under Cadmium Stress}

Protein extracts were separated by means of two-dimensional electrophoresis and after western blot, probed with a set of different monoclonal antibodies against tubulin. In the IEF 


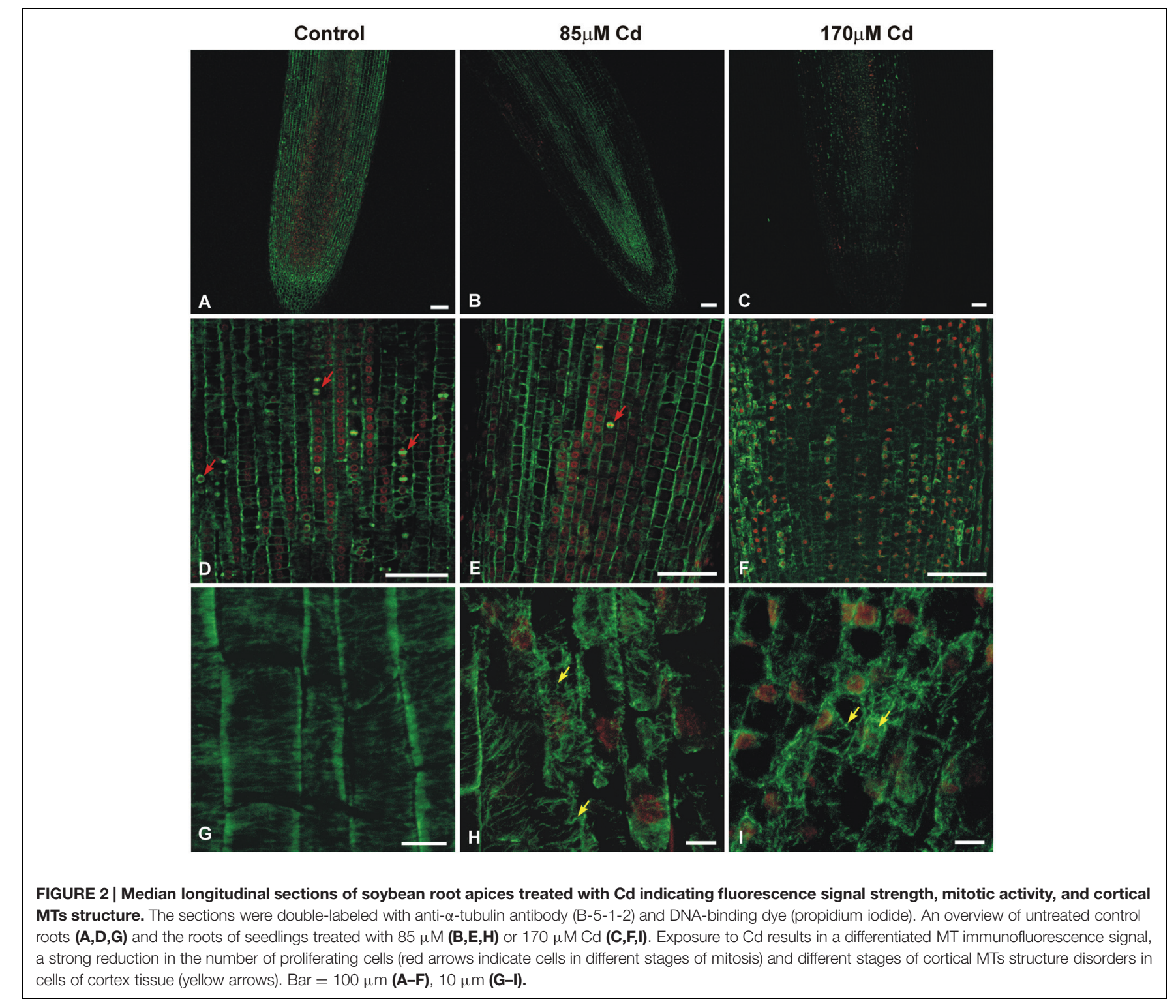

dimension, a very narrow $\mathrm{pH}$ gradient (4.7-5.9) of IPG strips were used, and a second dimension was carried out with precast SDS gels in order to improve the resolution and reproducibility of the tubulin isoforms. No cross-reaction with other proteins was observed and the secondary antibody alone gave no immunostaining signal. Moreover, the used antibodies stained all typical MT arrays appearing in plant cells during the cell cycle, including cortical MT, mitotic spindle and phragmoplast.

The most abundant electrophoretic pattern was found in control roots examined with antibody B-5-1-2, where six different isoforms of $\alpha$-tubulin were identified ( $\alpha 1-$ a6), which have been numbered according to their position from acidic to basic $\mathrm{pH}$ (Figure 5A). The immunodetected isotubulins possess an average molecular mass of around $50 \mathrm{kDa}$ and differ in their isoelectric points (pIs) ranging from approximately 5.1-5.3. After Cd treatment, the level of identified spots progressively decreased, and under high stress (170 $\mu \mathrm{M} \mathrm{Cd}$ ) the less pronounced $\alpha 1$ and $\alpha 6$ isotubulins were hardly detectable. The observed tendencies were verified by immunoblotting with other specific antibodies against $\alpha$-tubulin (TU-01, Figure 5B) and $\beta$-tubulin (TU-06, Figure 5C). The first antibody recognized five distinct isoforms of $\alpha$-tubulin, which in terms of $\mathrm{pI}$ and molecular masses corresponded to isotubulins $\alpha 2, \alpha 3, \alpha 4, \alpha 5$, and $\alpha 6$ detected with B-5-1-2 antibody. In turn, the anti- $\beta$-tubulin antibody immunostaining made it possible to visualize four isoforms $(\beta 1-\beta 4)$, which were focused in a distinct single cluster. The $\beta$-isotubulins were slightly more acidic in the IEF first dimension, and their $\mathrm{pI}$ values were in the approximate range 5.0-5.2. Similar to B-5-1-2 and TU-01 antibodies, the accumulation level of $\beta$-tubulin isoforms, recognized with TU-06 antibody, decreased significantly after $\mathrm{Cd}$ treatment, especially at high concentration of the metal. 

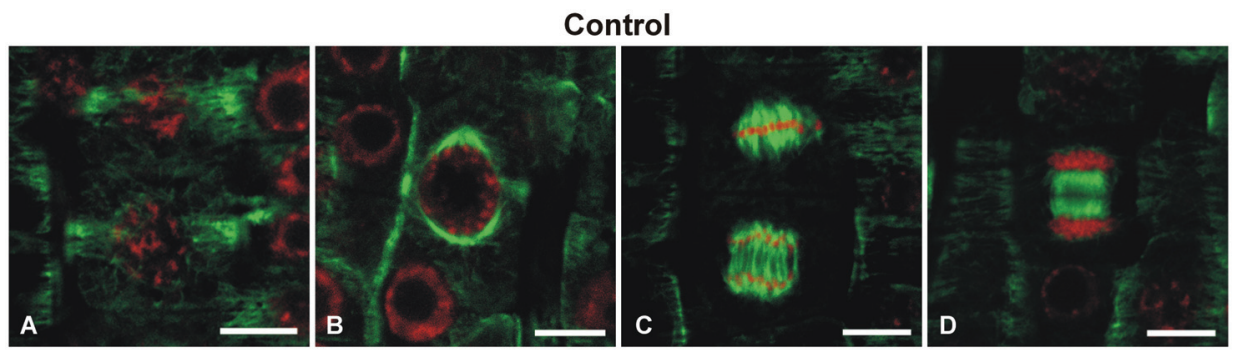

$85 \mu \mathrm{M} \mathrm{Cd}$
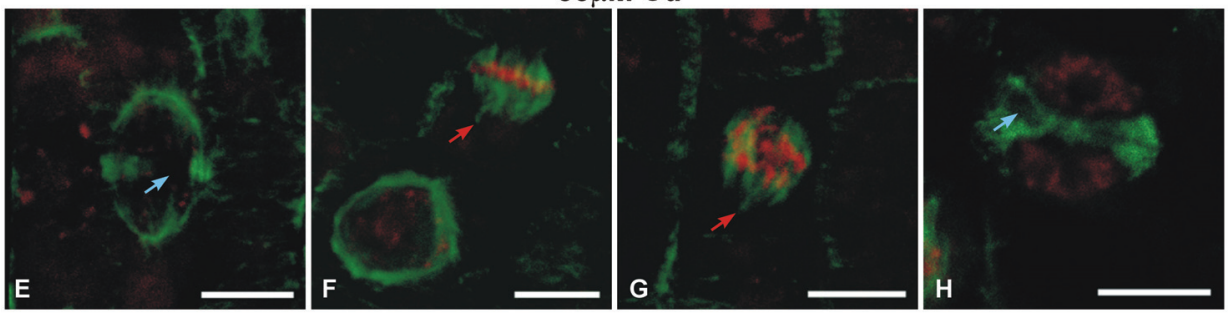

FIGURE 3 | Images showing the effects of moderate Cd (85 $\mu$ M) treatment on the mitotic MT arrays of soybean root apical cells. Merged images of immunofluorescence-labeled MTs and propidium iodide-stained nuclei. Cells of control roots displaying preprophase band (A), perinuclear spindle (B), mitotic spindle (C) and phragmoplast (D). Different mitotic arrays disorders (arrows) under Cd stress (E-H). Bar $=10 \mu \mathrm{m}$.

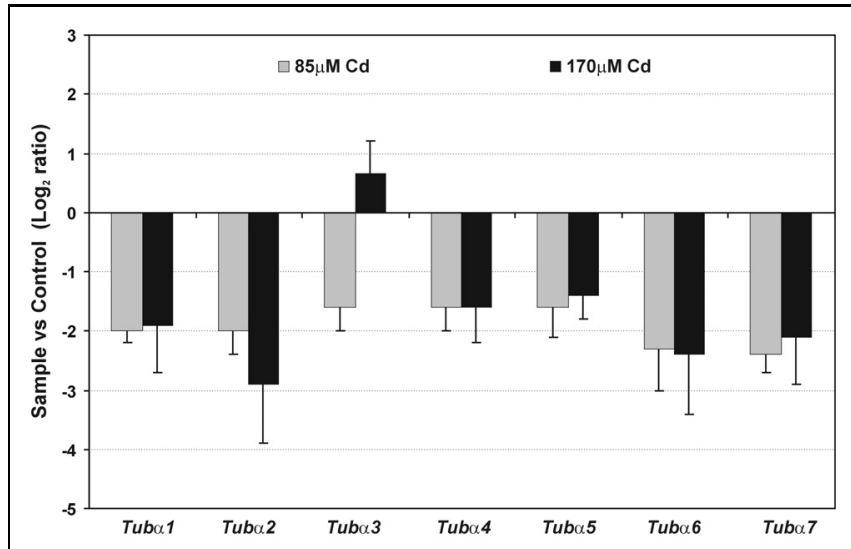

FIGURE 4 | Relative expression of gene encoding $\alpha$-tubulin isotypes. Fold change evaluated through real time PCR after moderate (85 $\mu \mathrm{M} \mathrm{Cd})$ and high (170 $\mu \mathrm{M} \mathrm{Cd}$ ) metal treatment. Values shown in the histogram are represented as a $\log _{2}$ fold change compared to the control sample average of 0 (untreated seedlings). The results represent the mean (+SE) of three separate experiments.

\section{Post-Translational Modifications of Tubulin Under Cadmium Stress}

Post-translational modifications were examined with the set of different specific antibodies recognizing tyrosinated, detyrosinated, acetylated, and polyglutamylated isoforms of tubulin (Figure 6). The use of the antibody TUB-1A2, which recognizes a peptide containing the carboxy terminal amino acid tyrosine of $\alpha$-tubulin, enabled detection of 11 isoforms ( $\alpha \mathrm{T} 1-\alpha \mathrm{T} 11$, Figure 6A). The distinguished isoforms were focused in two distinct clusters of spots. The first cluster consisted of four more acidic isoforms ( $\alpha \mathrm{T} 1-\alpha \mathrm{T} 4)$ with a molecular mass of about $50 \mathrm{kDa}$ and pIs at the range 5.15.3. The isoforms in the first cluster were identical in terms of molecular mass and pI values, with tubulin spots $\alpha 2-\alpha 5$ recognized with B-5-1-2 antibody. After Cd treatment, the intensity of the spots progressively decreased and under high stress $(170 \mu \mathrm{M})$ the more acidic isoforms ( $\alpha \mathrm{T} 1$ and $\alpha \mathrm{T} 2)$ were hardly detectable (Figure 6A). The second cluster of spots ( $\alpha \mathrm{T} 5-\alpha \mathrm{T} 11)$ migrated more slowly in the SDS-PAGE second dimension than in the first one, and the tubulin isoforms were slightly less acidic. The most abundant isoforms $\alpha$ T8$\alpha \mathrm{T} 11$ were relatively stable after $\mathrm{Cd}$ treatment. In contrast, spots $\alpha \mathrm{T} 5-\alpha \mathrm{T} 7$, which were weakly recognized in the control roots, became more abundant in roots treated with the metal (Figure 6A).

A differential signal was also detected in the recognition of detyrosinated isoforms of $\alpha$-tubulin (Glu-tubulin), where a population of 10 distinct spots $(\alpha \mathrm{G} 1-\alpha \mathrm{G} 10)$ was distinguished (Figure 6B). The molecular mass of spots was around $50 \mathrm{kDa}$, but their $\mathrm{pI}$ values extended over the range of approximately 5.1-5.5. The relative level of most recognized spots significantly decreased in comparison to the control roots, especially under high Cd stress $(170 \mu \mathrm{M})$, where some spots $(\alpha \mathrm{G} 1, \alpha \mathrm{G} 2)$ were not detectable. On the other hand, the accumulation of three tubulin isoforms: $\alpha \mathrm{G} 3, \alpha \mathrm{G} 5$, and $\alpha \mathrm{G} 6$ significantly increased in Cd-treated roots (Figure 6B). Additionally, spots $\alpha \mathrm{G} 4, \alpha \mathrm{G} 7$, and $\alpha \mathrm{G} 8$ corresponded in terms of molecular mass and $\mathrm{pI}$ values to isoforms $\alpha 4$ (Figure 5A), $\alpha \mathrm{T} 9$ and $\alpha \mathrm{T} 10$ (Figure 6A), recognized with B-5-1-2 or TUB-1A2 antibodies, respectively.

To identify the isoforms post-translationally modified by acetylation, the antibody 6-11B-1 was used, and nine spots of acetylated $\alpha$-tubulins ( $\alpha \mathrm{A} 1-\alpha \mathrm{A} 9$ ) were recognized (Figure 6C). The molecular masses of spots were approximately $50 \mathrm{kDa}$ and 

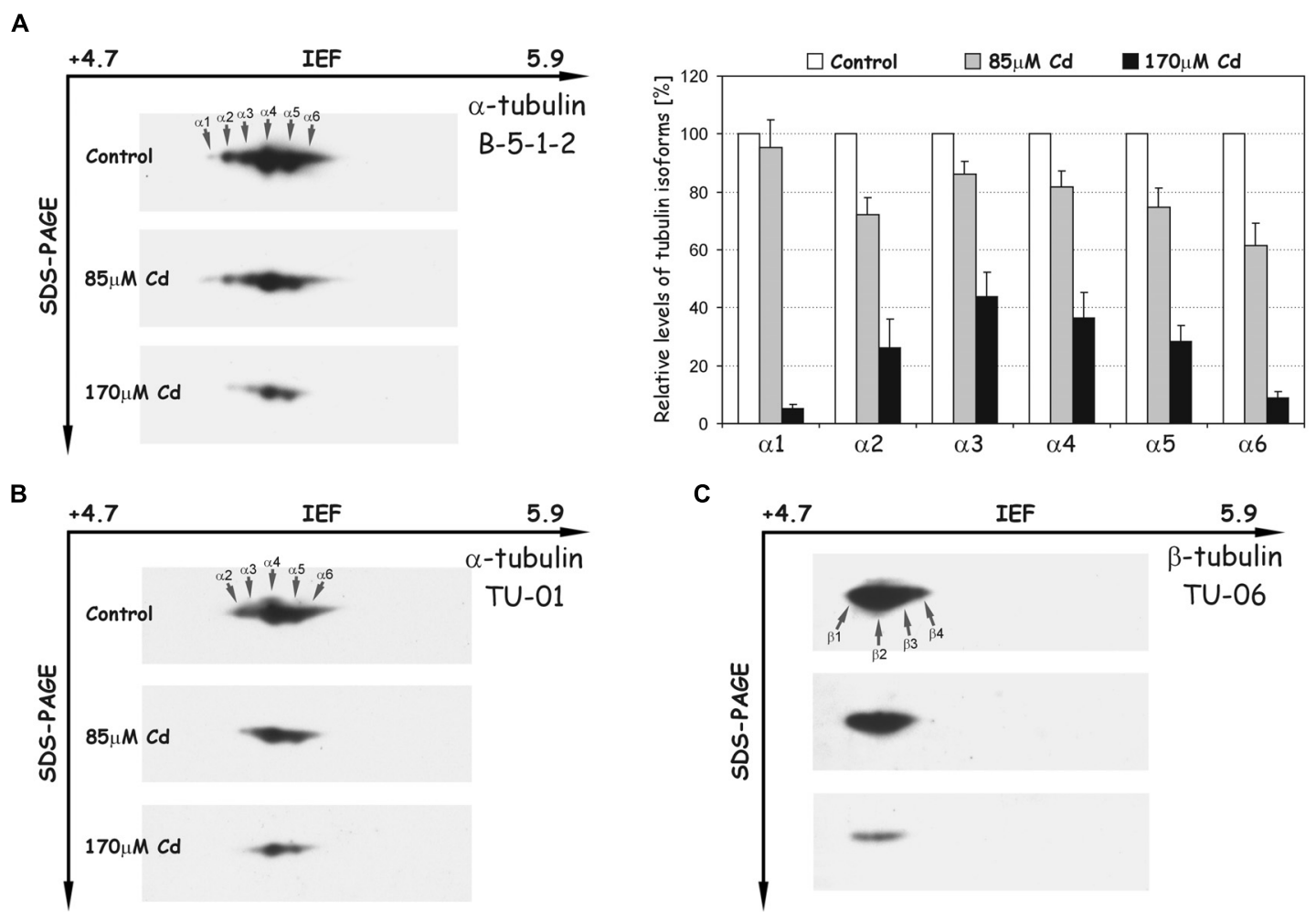

FIGURE 5 | Representative immunoblots probed with different antibodies against $\alpha$-tubulin (A,B) and $\beta$-tubulin isoforms (C). Individual tubulin isoforms are denoted by arrows marked $\alpha 1-\alpha 6$ for $\alpha$-tubulin and $\beta 1-\beta 4$ for $\beta$-tubulin. The quantitative results for $\alpha$-tubulin (antibody B-5-1-2) were calculated as a ratio of pixel intensity values to area of spots and data were presented considering the control as a reference point (100\%). The values represent the average of three independent measurements with a standard deviation.

their pI values extended between 5.1 and 5.9. The level of lesspronounced spots $\alpha$ A4- $\alpha$ A9 significantly decreased under high $\mathrm{Cd}$ stress compared to control and moderate stress $(85 \mu \mathrm{M}$ $\mathrm{Cd})$ levels. A quite opposite situation was observed in the case of more acidic and more pronounced isoforms $\alpha \mathrm{A} 2$ and $\alpha \mathrm{A} 3$, where a progressive increase in their accumulation occurred (Figure 6C). Moreover, spots $\alpha \mathrm{A} 3, \alpha \mathrm{A} 4, \alpha \mathrm{A} 5$, and $\alpha \mathrm{A} 6$ were identical in regard to their $\mathrm{pI}$ values and molecular masses with isoforms $\alpha 4$ (Figure 5A), $\alpha \mathrm{T} 9, \alpha \mathrm{T} 10$ (Figure 6A) and $\alpha \mathrm{G} 10$ (Figure 6B), identified with B-5-1-2, TUB-1A2 and anti-Glutubulin (6-11B-1) antibodies, respectively.

In the next set of experiments the polyglutamylation of proteins with GT335 antibody was examined. A pattern of 14 polypeptides (I-XIV) with glutamate side chains was recognized (Figure 6D). The isoelectric points and molecular masses of the distinguished spots were in the range of $5.2-5.7$ and $45-50 \mathrm{kDa}$, respectively. The level of detected peptides under $\mathrm{Cd}$ stress changed differentially. On the one hand, the accumulation of polypeptides I, III, V, VIII, IX, X, and XII progressively decreased under moderate and high stress (Figure 6D). On the other hand, the level of spots II, IV, VI, VII, and XIV distinctively increased after Cd treatment. Moreover, the polypeptides I, III, VIII, X, and XII were identical in terms of $\mathrm{pI}$ values and molecular masses with tubulin isoforms $\alpha 4, \alpha 5$ (Figure 5A), $\alpha \mathrm{T} 9, \alpha \mathrm{T} 10$ (Figure 6A) and $\alpha \mathrm{A6}$ (Figure 6C), respectively.

\section{Cadmium Effects on the Ultrastructure of Root Cells}

At the ultrastructural level, the cells of control roots displayed thin cell walls and dense cytoplasm filled with numerous organelles and structures including mitochondria, endoplasmic reticulum, and dictyosomes (Figure $7 \mathbf{A}$ ). In the presence of $\mathrm{Cd}$, distinct changes in the ultrastructure were observed, the most prominent of which included development of one central located vacuole (Figure 7B) and irregular deposition of callose, especially in high Cd treatment (Figure 7C).

\section{DISCUSSION}

The plant MT cytoskeleton promptly rebuilds its arrangement in response to various intracellular and external stimuli, including abiotic stresses (Smertenko et al., 1997c; Schwarzerová et al., 2002; Shoji et al., 2006; Lü et al., 2007; Liu et al., 2009; Xu et al., 2009). The results presented in this study confirmed that both root growth and structure of MTs are very sensitive to $\mathrm{Cd}$ treatment. Previous studies performed in our department revealed that soybean seedlings respond to $\mathrm{Cd}$ in the range of the applied concentrations differentially in the terms of antioxidant response (Pawlak et al., 2009), activation of phenylpropanoid pathway (Pawlak-Sprada et al., 2011) and expression of signaling 
A

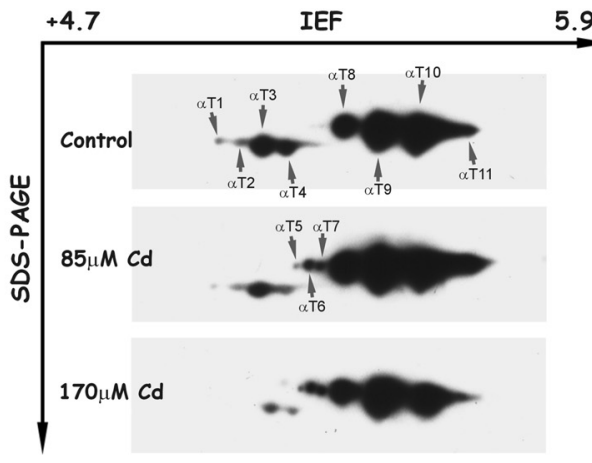

B
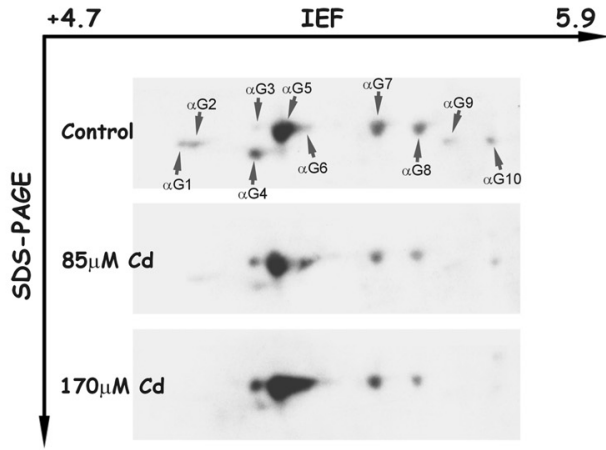

C

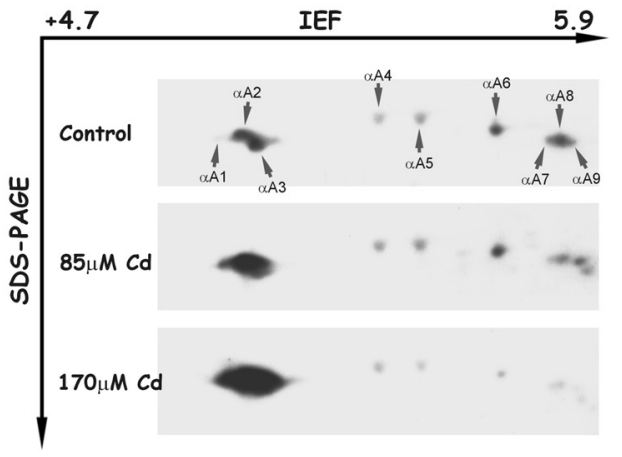

D

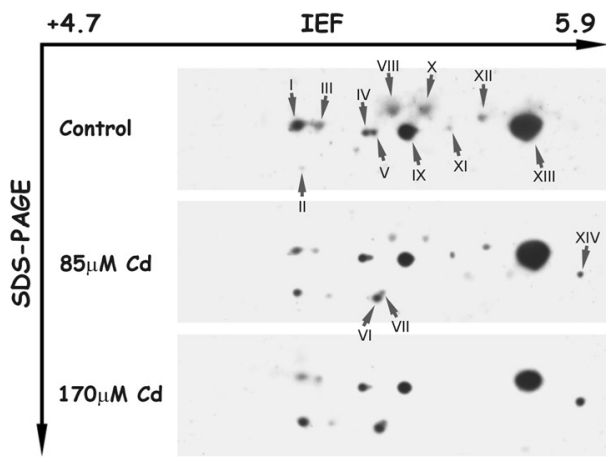

5.9
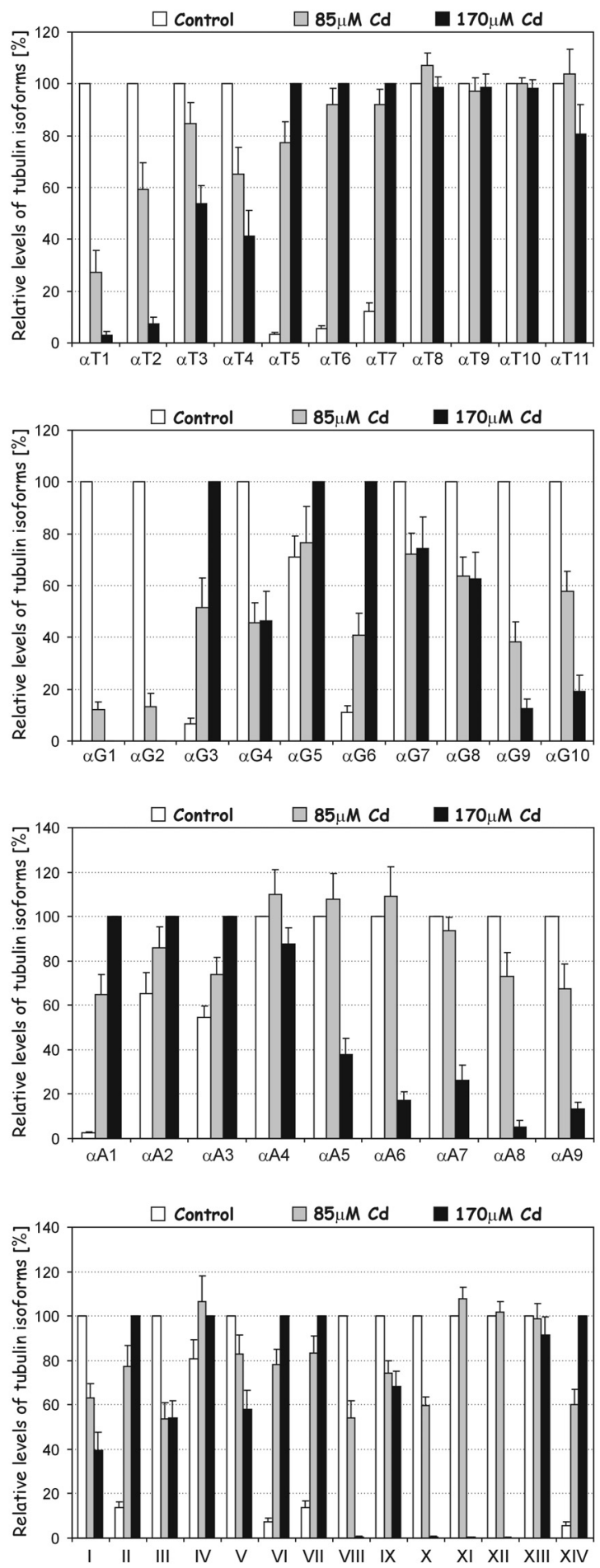

FIGURE 6 | Representative immunoblots probed with a set of different antibodies against tyrosinated $\alpha$-tubulin (A), detyrosinated $\alpha$-tubulin (B), acetylated $\alpha$-tubulin (C) and polyglutamylated proteins (D). Individual tubulin isoforms (spots) are denoted by arrows marked: $\alpha \mathrm{T} 1-\alpha \mathrm{T} 11$ (tyrosinated isoforms), $\alpha \mathrm{G} 1-\alpha \mathrm{G} 10$ (detyrosinated isoforms), $\alpha \mathrm{A} 1-\alpha \mathrm{A}$ (acetylated isoforms) and I-XIV (polyglutamylated proteins). The quantitative results were calculated as a ratio of pixel intensity values to the area of spots, and the data were presented considering the control or $170 \mu \mathrm{M} \mathrm{Cd}$ as a reference point (100\%). Values represent the average of three independent measurements with a standard deviation. 


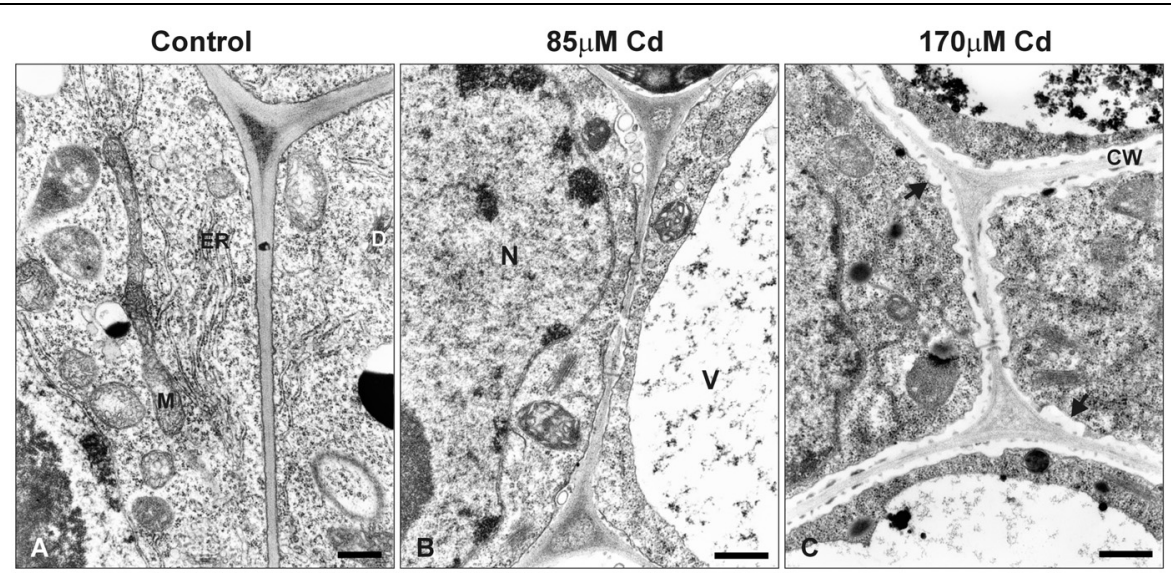

FIGURE 7 | Electron micrographs of the root tip cells of control seedlings (A) and plants treated with moderate (B) or high (C) Cd concentrations (85 or $\mathbf{1 7 0} \mu \mathbf{M}$ Cd, respectively). M, mitochondrion; N, nucleus; V, vacuole; ER, endoplasmic reticulum; D, dictyosome; CW, cell wall. Black arrows indicate irregular deposition of callose in the root cells of Cd-treated seedlings. Bar $=500 \mathrm{~nm}$.

associated genes (Chmielowska-Bąk et al., 2013). Moreover, this study demonstrates that root tips in high Cd stress $(170 \mu \mathrm{M})$, contrary to moderate stress $(85 \mu \mathrm{M})$, were distinguished by the lack of dividing cells (Figure 2) and more advanced callose deposition (Figure 7C). It can be concluded that increasing concentrations of the metal and resulting reduction in root growth were strongly correlated with a drop in the number of mitotic cells and an increase in abnormalities in MT structure (Figures 2 and 3). A similar pattern of MT dysfunction under short-term Cd treatment $(0.5-24 \mathrm{~h})$ was observed in the root tips of garlic (Xu et al., 2009), pea (Fusconi et al., 2007), and onion (Dovgalyuk et al., 2003) treated with very low (0.25 or $10 \mu \mathrm{M})$ to relatively high concentrations of the metal (50$250 \mu \mathrm{M})$. A significant reduction in the number of mitotic cells is in line with other studies showing that exposure to $\mathrm{Cd}$ arrests the entrance of the cells into a division cycle (Fusconi et al., 2006; Amirthalingam et al., 2013; Arya and Mukherjee, 2014; Shi et al., 2014). Thus, it seems to be well established that regardless of the plant species or experimental setup, a general feature of $\mathrm{Cd}$ toxicity is the rapid and sensitive response of the MT cytoskeleton connected with a decrease in the mitotic index. As yet, the exact mechanism of noxious Cd action toward MTs is not well understood. There are a few possibilities which include indirect $\mathrm{Cd}$ influence on MTs functioning by effecting the expression of tubulin genes, PTMs of the expressed proteins, and MAPs dysfunction. On the other hand, the direct interaction of the metal with the sulfhydryl groups of MTs, which are essential for MT polymerization, cannot be excluded (Wallin and HartleyAsp, 1993).

In our study 7 genes for $\alpha$-tubulin were examined. Most of the examined genes were down regulated after $\mathrm{Cd}$ treatment with the exception of $T u b \alpha 3$, which under high metal stress was slightly up-regulated (Figure 4). It is assumed that each plant species has evolved diverse sets of tubulin genes, which generate significant heterogeneity in the number of $\alpha$ - and $\beta$-tubulin isotypes. Consequently, isotypes of tubulin are differentially expressed in relation to the specific organ/tissue, developmental stage or changed environmental conditions (Breviario et al., 2013). Thus, in the context of the high heterogeneity of plant tubulin genes, one cannot exclude the participation of particular isotypes in specific processes. There are, for example, several premises that specific tubulin isotypes are associated with the synthesis of secondary cell wall layers. In Eucalyptus grandis expression pattern of specific $\beta$-tubulin gene was correlated with the deposition of the cell wall (Spokevicius et al., 2007). Moreover, in Populus increase in cellulose synthesis was accompanied by elevated expression of some $\beta$-tubulin isotypes (Oakley et al., 2007). In the present study, ultrastructure analysis of soybean root cells revealed that after high Cd treatment $(170 \mu \mathrm{M})$, a noticeable deposition of callose occurred (Figure 7C), which may be considered as a cellular defense reaction by modification of cell wall properties to prevent metal uptake or enable its immobilization in cell walls (Krzesłowska, 2011; Eleftheriou et al., 2012; Piršelová et al., 2012). This result together with the observed induction of Tuba 3 gene in response to high Cd concentration might suggest that expression of at least some tubulin genes is also process-specific - induction of specific isotypes might be advantageous in stress conditions (Breviario and Nick, 2000). However, the majority of examined genes were significantly down-regulated after $\mathrm{Cd}$ treatment (Figure 4), but there was no differences in transcript level between moderate and high Cd concentrations. At the same time, the western blot analyses demonstrated reduction in the accumulation of tubulin isoforms in the concentration dependent manner (Figure 5). The observed discrepancy might result from modulation of various post-transcriptional and post-translational mechanisms (Maier et al., 2009; Vélez-Bermúdez and Schmidt, 2014). For example, translation efficiency might be impaired by miRNAs, changes in mRNA structure or hampered assembly of ribosome-mRNA complexes. Additionally, it can not be excluded that different $\mathrm{Cd}$ concentrations might have distinct impact on the lifetime of synthesized proteins.

The disturbance observed in MTs functioning was accompanied not only by lower accumulations of $\alpha$ - and 
$\beta$-tubulin isoforms, but also by significant changes in the level of their PTMs. In our experimental approach we used the set of commercial antibodies against PTMs, which have been used successfully in other plant species (Smertenko et al., 1997a; Wang et al., 2004; Parrotta et al., 2010; Nakagawa et al., 2013). Based on animal and human cell models it is well documented that PTMs can modify interactions with MAPs (Verhey and Gaertig, 2007). A good example are plus-end tracking proteins (+TIPs), a highly diverse group of MAPs, which help control MT interactions by dynamic accumulation at the distal, highly tyrosinated ends of growing MTs (Akhmanova and Hoogenraad, 2005; Hammond et al., 2008). In this way, tyrosination of MTs guides +TIPs localization and influences their function. It is assumed that stable MTs exhibiting less dynamic behavior are enriched in detyrosinated tubulin subunits, while dynamic MTs include tyrosinated tubulin subunits (Webster et al., 1987; Bulinski and Gundersen, 1991). The results presented in this paper imply that Cd contributes to stabilization of the MTs because the level of a quite large part of tyrosinated tubulin isoforms (e.g., $\alpha \mathrm{T} 1-\alpha \mathrm{T} 4$ ) significantly decreased in a metal-concentration dependent manner (Figure 6A). Moreover, the tyrosinated isoforms ( $\alpha \mathrm{T} 1-$ $\alpha \mathrm{T} 4)$ were also identical in terms of their pIs and molecular masses to down-regulated tubulin isoforms $(\alpha 2-\alpha 5)$ recognized with B-5-1-2 and TU-01 antibodies (Figure 5). Simultaneously, the general level of the most pronouncedly detyrosinated isoforms increased (Figure 6B); however, the pattern of this modification was not unequivocal. Although, detyrosination of one of the $\alpha$-tubulin isoform ( $\alpha \mathrm{G} 4)$ was markedly diminished under stress conditions, at the same time, a significant increase of other isoforms ( $\alpha \mathrm{G} 3, \alpha \mathrm{G} 5$, and $\alpha \mathrm{G} 6)$ occurred.

A similar situation was observed in the case of acetylated isoforms, where the most pronounced isotubulins $\alpha \mathrm{A} 2$ and $\alpha \mathrm{A} 3$ significantly increased under stress conditions (Figure 6C). Acetylation of tubulin is mainly considered a marker of stable MTs resistant to turnover (Webster and Borisy, 1989), albeit tubulin acetylation has been also discovered on dynamic MTs (Perdiz et al., 2011). The function of acetylated MTs still remains unclear, and most suggestions concern human cells functioning. It is proposed that acetylation, similar to tyrosination/detyrosination modifications, can influence the transport and binding of MAPs to selected MTs (Gardiner et al., 2007). However, most interactions between MAPs and MTs take place on the outer surface of MTs, and it remains a mystery how acetylated tubulin serves as a guide for MAPs because the primary site of tubulin acetylation Lys 40 is orientated toward the MT lumen. However, the use of a proteomic approach allowed recognition of some new sites of tubulin acetylation, some of which are exposed on the outer surface of MTs (Choudhary et al., 2009). Therefore, a plant-specific site of tubulin acetylation on the outer surface of the MT can also not be excluded. A similar pattern in tubulin PTMs was observed in the sponge Clathrina clathrus, where exposure to a sublethal concentration of $\mathrm{Cd}$ for $24 \mathrm{~h}$ reduced the level of tyrosinated $\alpha$-tubulin and simultaneously enhanced the level of detyrosinated and acetylated $\alpha$-tubulin (Ledda et al., 2013). The predominance of our study is the higher resolution of tubulin electrophoretic separation due to the application of
2D technique enabling gaining insight into the population of particular tubulin isoforms. We have shown that among the tubulin isoforms, in some the level of modifications increased (e.g., $\alpha \mathrm{T} 5-\alpha \mathrm{T} 7)$, but at the same time, the other detected isotubulins exhibited a lower level of modifications compared to control variants (e.g., $\alpha \mathrm{T} 1-\alpha \mathrm{T} 4)$. The obtained results draw attention to the fact that apart from the general level of PTMs, their great significance under stress or altered environmental conditions might be associated with increased modification of particular tubulin isoforms, which in turn might be derived from specific isotypes of tubulin. Nonetheless, it has been shown that evolutionarily distant organisms such as sponge and soybean exhibited a similar pattern of response to Cd stress. The overaccumulation of detyrosinated and acetylated $\alpha$-tubulins with a concurrent depletion of tyrosinated tubulin might be a general mechanism involved in maintaining the efficient structural and functional integrity of the MT cytoskeleton under Cd stress. This assumption might be strengthened by the observations of MT cytoskeleton functioning under other heavy metal stress like hexavalent chromium. The studies of different Fabaceae species indicate on MTs stabilization by increased acetylation of $\alpha$-tubulin in a time- and concentration-dependent manner under chromium stress (Eleftheriou et al., 2013, 2015).

The putative increase in stability of the MT structure after Cd treatment seems to be in line with changes observed in the accumulation of polyglutamylated isoforms. In our study we recognized a population of 14 spots which were modified by the addition of one or more glutamate residues, but only five of them (I, III, VIII, X, and XII) have identical properties in terms of pIs and molecular masses with tubulin isoforms recognized with B-5-1-2, 6-11B-1, and TUB-1A2 antibodies (Figures 5 and 6). However, one should bear in mind that the antibody GT335, conversely to other antibodies applied here, might recognize some other proteins modified by glutamylation. Thus, the rest of the spots might not be related to tubulin proteins or, due to the right $\mathrm{pI}$ and molecular masses, might be associated, in at least some cases, with $\beta$-tubulin isoforms or $\gamma$-tubulin proteins. In our study the highest levels of polyglutamylated tubulin isoforms were recognized in control roots, and significantly decreased after Cd treatment, especially at high concentration of the metal, where some of them (VIII and X) were almost undetectable (Figure 6D). The exact function and significance of tubulin polyglutamylation is elusive and hypothetical, especially in plant cells. However, studies on human cells demonstrated that glutamylation, and in particular the generation of long glutamate side chains, promotes the severing of MTs and in this way provides a novel mechanism for controlling the mass and stability of MTs (Lacroix et al., 2010). By analogy, if the same mechanism is functioning in plant cells, the decreased level of polyglutamylated isotubulins revealed in Cd-treated seedlings would restrict the MT-severing activity and prevent disassembles of stable MTs. This would be consistent with the results obtained with the use of antibodies against detyrosinated and acetylated isoforms of tubulin, which seems to indicate the increased stability of MTs after Cd treatment.

Taken together, the results obtained in this study confirmed that the MT cytoskeleton is one of the cellular structures most 
sensitive to $\mathrm{Cd}$ stress. The vast majority of examined $\alpha$-tubulin genes together with most of recognized $\alpha$ - and $\beta$-tubulin isoforms were down-regulated. However, for the first time in plants, changes in PTMs level of tubulin isoforms after Cd treatment were demonstrated. The immunological approach with the use of a set of antibodies against different PTMs of tubulin imply the increased stability and reduced turnover of MTs during stress conditions. The stability of MTs in Cd-treated seedlings might be associated with a general increase in the levels of some detyrosinated and acetylated isoforms. On the other hand, the level of some tyrosinated and polyglutamylated tubulin isoforms, which are assumed to favor the dynamic turnover of MT fibers, decreased. A shift in MT dynamics to more stable MT fibers would enable preferential transport and cell wall modification, e.g., callose deposition, which prevent $\mathrm{Cd}$ uptake or enable its immobilization in cell walls. The stable MTs enable the molecular motors to reach their destination,

\section{REFERENCES}

Akhmanova, A., and Hoogenraad, C. C. (2005). Microtubule plus-end-tracking proteins: mechanisms and functions. Curr. Opin. Cell Biol. 17, 47-54. doi: 10.1016/j.ceb.2004.11.001

Amirthalingam, T., Velusamy, G., and Pandian, R. (2013). Cadmium-induced changes in mitotic index and genotoxicity on Vigna unguiculata (Linn.) Walp. J. Environ. Chem. Ecotoxicol. 5, 57-62.

Arya, S. K., and Mukherjee, A. (2014). Sensitivity of Allium cepa and Vicia faba towards cadmium toxicity. J. Soil Sci. Plant Nutr. 14, 447-458.

Ban, Y., Kobayashi, Y., Hara, T., Hamada, T., Hashimoto, T., Takeda, S., et al. (2013). $\alpha$-Tubulin is rapidly phosphorylated in response to hyperosmotic stress in rice and arabidopsis. Plant Cell Physiol. 54, 848-858. doi: 10.1093/pcp/pct065

Blume, Y., Yemets, A., Sulimenko, V., Sulimenko, T., Chan, J., Lloyd, C., et al. (2008). Tyrosine phosphorylation of plant tubulin. Planta 229, 143-150. doi: 10.1007/s00425-008-0816-z

Breviario, D., Gianì, S., and Morello, L. (2013). Multiple tubulins: evolutionary aspects and biological implications. Plant J. 75, 202-218. doi: 10.1111/tpj.12243

Breviario, D., and Nick, P. (2000). Plant tubulins: a melting pot for basic questions and promising applications. Transgenic Res. 9, 383-393. doi: 10.1023/A:1026598710430

Bulinski, J. C., and Gundersen, G. G. (1991). Stabilization and post-translational modification of microtubules during cellular morphogenesis. Bioessays 13, 285-293. doi: 10.1002/bies.950130605

Chmielowska-Bąk, J., Lefèvre, I., Lutts, S., and Deckert, J. (2013). Short term signaling responses in roots of young soybean seedlings exposed to cadmium stress. J. Plant Physiol. 170, 1585-1594. doi: 10.1016/j.jplph.2013.06.019

Choudhary, C., Kumar, C., Gnad, F., Nielsen, M. L., Rehman, M., Walther, T. C., et al. (2009). Lysine acetylation targets protein complexes and co-regulates major cellular functions. Science 325, 834-840. doi: 10.1126/science.1175371

Dalcorso, G., Manara, A., and Furini, A. (2013). An overview of heavy metal challenge in plants: from roots to shoots. Metallomics 5, 1117-1132. doi: $10.1039 / \mathrm{c} 3 \mathrm{mt} 00038 \mathrm{a}$

Del Duca, S., Serafini-Fracassini, D., Bonner, P., Cresti, M., and Cai, G. (2009). Effects of post-translational modifications catalysed by pollen transglutaminase on the functional properties of microtubules and actin filaments. Biochem. J. 418, 651-664. doi: 10.1042/BJ20081781

Dovgalyuk, A., Kalynyak, T., and Blume, Y. B. (2003). Heavy metals have a different action from aluminium in disrupting microtubules in Allium cepa meristematic cells. Cell Biol. Int. 27, 193-195. doi: 10.1016/S1065-6995(02)00334-7

Eleftheriou, E. P., Adamakis, I. D. S., Fatsiou, M., and Panteris, E. (2013). Hexavalent chromium disrupts mitosis by stabilizing microtubules in Lens culinaris root tip cells. Physiol. Plant. 147, 169-180. doi: 10.1111/j.13993054.2012.01652.x avoiding an unfavorable situation in which the MT track falls apart.

\section{AUTHOR CONTRIBUTIONS}

JG, RP, EG conceived and designed research. JG carried out immunocytochemistry, ultrastructure, 2D electrophoresis and western blot experiments, JC-B conducted real-time PCR experiments. All authors analyzed the data. JG wrote the manuscript. All authors read and approved the manuscript.

\section{ACKNOWLEDGMENT}

This work was supported by funds from the Ministry of Science and Higher Education, Poland (project no. N N303 537938)

Eleftheriou, E. P., Adamakis, I. D. S., and Melissa, P. (2012). Effects of hexavalent chromium on microtubule organization. ER distribution and callose deposition in root tip cells of Allium cepa L. Protoplasma 249, 401-416. doi: 10.1007/s00709-011-0292-3

Eleftheriou, E. P., Adamakis, I. D. S., and Michalopoulou, V. A. (2015). Hexavalent chromium-induced differential disruption of cortical microtubules in some Fabaceae species is correlated with acetylation of $\alpha$-tubulin. Protoplasma doi: 10.1007/s00709-015-0831-4 [Epub ahead of print].

Fusconi, A., Gallo, C., and Camusso, W. (2007). Effects of cadmium on root apical meristems of Pisum sativum L.: cell viability, cell proliferation and microtubule pattern as suitable markers for assessment of stress pollution. Mutat. Res. Genet. Toxicol. Environ. Mutagen. 632, 9-19. doi: 10.1016/j.mrgentox.2007. 03.012

Fusconi, A., Repetto, O., Bona, E., Massa, N., Gallo, C., Dumas-Gaudot, E., et al. (2006). Effects of cadmium on meristem activity and nucleus ploidy in roots of Pisum sativum L. cv. Frisson seedlings. Environ. Exp. Bot. 58, 253-260. doi: 10.1016/j.envexpbot.2005.09.008

Gardiner, J., Barton, D., Marc, J., and Overall, R. (2007). Potential role of tubulin acetylation and microtubule-based protein trafficking in familial dysautonomia. Traffic 8, 1145-1149. doi: 10.1111/j.1600-0854.2007.00605.x

Gilmer, S., Clay, P., MacRae, T. H., and Fowke, L. C. (1999a). Acetylated tubulin is found in all microtubule arrays of two species of pine. Protoplasma 207, 174-185. doi: 10.1007/BF01282998

Gilmer, S., Clay, P., MacRae, T. H., and Fowke, L. C. (1999b). Tyrosinated, but not detyrosinated, $\alpha$-tubulin is present in root tip cells. Protoplasma 210, 92-98. doi: 10.1007/BF01314959

Hamada, T. (2007). Microtubule-associated proteins in higher plants. J. Plant Res. 120, 79-98. doi: 10.1007/s10265-006-0057-9

Hammond, J. W., Cai, D., and Verhey, K. J. (2008). Tubulin modifications and their cellular functions. Curr. Opin. Cell Biol. 20, 71-76. doi: 10.1016/j.ceb.2007.11.010

Horio, T., and Murata, T. (2014). The role of dynamic instability in microtubule organization. Front. Plant. Sci. 5:511. doi: 10.3389/fpls.2014.00511

Krzesłowska, M. (2011). The cell wall in plant cell response to trace metals: polysaccharide remodeling and its role in defense strategy. Acta Physiol. Plant. 33, 35-51. doi: 10.1007/s11738-010-0581-z

Lacroix, B., Van Dijk, J., Gold, N. D., Guizetti, J., Aldrian-Herrada, G., Rogowski, K., et al. (2010). Tubulin polyglutamylation stimulates spastin-mediated microtubule severing. J. Cell Biol. 189, 945-954. doi: 10.1083/jcb.201001024

Ledda, F. D., Ramoino, P., Ravera, S., Perino, E., Bianchini, P., Diaspro, A., et al. (2013). Tubulin posttranslational modifications induced by cadmium in the sponge Clathrina clathrus. Aquat. Toxicol. 14, 98-105. doi: 10.1016/j.aquatox.2013.05.013 
Liu, D., Xue, P., Meng, Q., Zou, J., Gu, J., and Jiang, W. (2009). Pb/Cu effects on the organization of microtubule cytoskeleton in interphase and mitotic cells of Allium sativum L. Plant Cell Rep. 28, 695-702. doi: 10.1007/s00299-00 9-0669-3

Lü, B., Gong, Z., Wang, J., Zhang, J., and Liang, J. (2007). Microtubule dynamics in relation to osmotic stress-induced ABA accumulation in Zea mays roots. J. Exp. Bot. 58, 2565-2572. doi: 10.1093/jxb/erm107

MacRae, T. H. (1997). Tubulin post-translational modifications. Enzymes and their mechanisms of action. Eur. J. Biochem. 244, 265-278. doi: 10.1111/j.14321033.1997.00265.x

Maier, T., Güell, M., and Serrano, L. (2009). Correlation of mRNA and protein in complex biological samples. FEBS Lett. 583, 3966-3973. doi: 10.1016/j.febslet.2009.10.036

Malea, P., Adamakis, I. D. S., and Kevrekidis, T. (2013). Kinetics of cadmium accumulation and its effects on microtubule integrity and cell viability in the seagrass Cymodocea nodosa. Aquat. Toxicol. 14, 257-264. doi: 10.1016/j.aquatox.2013.10.017

Méchin, V., Damerval, C., and Zivy, M. (2007). Total protein extraction with TCA-acetone. Methods Mol. Biol. 355, 1-8.

Nakagawa, U., Suzuki, D., Ishikawa, M., Sato, H., Kamemura, K., and Imamura, A. (2013). Acetylation of $\alpha$-tubulin on Lys40 is a widespread post-translational modification in angiosperms. Biosci. Biotechnol. Biochem. 77, 1602-1605. doi: 10.1271/bbb.130261

Oakley, R. V., Wang, Y. S., Ramakrishna, W., Harding, S. A., and Tsai, C. J. (2007). Differential expansion and expression of $\alpha$ - and $\beta$-tubulin gene families in Populus. Plant Physiol. 145, 961-973. doi: 10.1104/pp.107.107086

Parrotta, L., Cai, G., and Cresti, M. (2010). Changes in the accumulation of $\alpha$ - and $\beta$-tubulin during bud development in Vitis vinifera L. Planta 231, 277-291. doi: 10.1007/s00425-009-1053-9

Parrotta, L., Cresti, M., and Cai, G. (2014). Accumulation and post-translational modifications of plant tubulins. Plant Biol. 16, 521-527. doi: 10.1111/plb. 12104

Pawlak, S., Firych, A., Rymer, K., and Deckert, J. (2009). Cu,Zn-superoxide dismutase is differently regulated by cadmium and lead in roots of soybean seedlings. Acta Physiol. Plant. 31, 741-747. doi: 10.1007/s11738-009-0 286-3

Pawlak-Sprada, S., Arasimowicz-Jelonek, M., Podgórska, M., and Deckert, J. (2011). Activation of phenylpropanoid pathway in legume plants exposed to heavy metals. Part I. Effects of cadmium and lead on phenylalanine ammonialyase gene expression, enzyme activity and lignin content. Acta Biochim. Pol. 58, 211-216.

Perdiz, D., Mackeh, R., Poüs, C., and Baillet, A. (2011). The ins and outs of tubulin acetylation: more than just a post-translational modification? Cell. Signal. 23, 763-771. doi: 10.1016/j.cellsig.2010.10.014

Peris, L., Wagenbach, M., Lafanechère, L., Brocard, J., Moore, A. T., Kozielski, F., et al. (2009). Motor-dependent microtubule disassembly driven by tubulin tyrosination. J. Cell Biol. 185, 1159-1166. doi: 10.1083/jcb.2009 02142

Pfaffl, M. W. (2001). A new mathematical model for relative quantification in real-time RT-PCR. Nucleic Acids Res. 29:e45. doi: 10.1093/nar/29.9.e45

Piperno, G., LeDizet, M., and Chang, X. J. (1987). Microtubules containing acetylated alpha-tubulin in mammalian cells in culture. J. Cell Biol. 104, 289302. doi: $10.1083 /$ jcb.104.2.289

Piršelová, B., Mistríková, V., Libantová, J., Moravčíková, J., and Matušíková, I. (2012). Study on metal-triggered callose deposition in roots of maize and soybean. Biologia 67, 698-705.

Přibyl, P., Cepák, V., and Zachleder, V. (2005). Cytoskeletal alterations in interphase cells of the green alga Spirogyra decimina in response to heavy metals exposure: I. The effect of cadmium. Protoplasma 226, 231-240. doi: 10.1007/s00709-005-0123-5

Radchuk, V. V., Sreenivasulu, N., Blume, Y., and Weschke, W. (2007). Distinct tubulin genes are differentially expressed during barley grain development. Physiol. Plant. 131, 571-580. doi: 10.1111/j.1399-3054.2007.0 0976.x

Rascio, N., Dalla Vecchia, F., La Rocca, N., Barbato, R., Pagliano, C., Raviolo, M., et al. (2008). Metal accumulation and damage in rice (cv. Vialone nano) seedlings exposed to cadmium. . Environ. Exp. Bot. 62, 267-278. doi: 10.1016/j.envexpbot.2007.09.002
Schwarzerová, K., Zelenková, S., Nick, P., and Opatrný, Z. (2002). Aluminuminduced rapid changes in the microtubular cytoskeleton of tobacco cell lines. Plant Cell Physiol. 43, 207-216. doi: 10.1093/pcp/pcf028

Shi, H. P., Zhu, Y. F., Wang, Y. L., and Tsang, P. K. E. (2014). Effect of cadmium on cytogenetic toxicity in hairy roots of Wedelia trilobata L. and their alleviation by exogenous $\mathrm{CaCl}_{2}$. Environ. Sci. Pollut. Res. 21, 1436-1443. doi: 10.1007/s11356013-2015-0

Shoji, T., Suzuki, K., Abe, T., Kaneko, Y., Shi, H., Zhu, J.-K., et al. (2006). Salt stress affects cortical microtubule organization and helical growth in Arabidopsis. Plant Cell Physiol. 47, 1158-1168. doi: 10.1093/pcp/pcj090

Siddiqui, S., Meghvansi, M. K., Wani, M. A., and Jabee, F. (2009). Evaluating cadmium toxicity in the root meristem of Pisum sativum L. Acta Physiol. Plant. 31, 531-536. doi: 10.1007/s11738-008-0262-3

Smertenko, A., Blume, Y., Viklický, V., and Dráber, P. (1997a). Exposure of tubulin structural domains in Nicotiana tobacum microtubules probed by monoclonal antibodies. Eur. J. Cell Biol. 72, 104-112.

Smertenko, A., Blume, Y., Viklický, V., Opatrný, Z., and Dráber, P. (1997b). Posttranslational modifications and multiple tubulin isoforms in Nicotiana tabacum L. cells. Planta 201, 349-358. doi: 10.1007/s004250050077

Smertenko, A., Dráber, P., Viklický, V., and Opatrný, Z. (1997c). Heat stress affects the organization of microtubules and cell division in Nicotiana tabacum cells. Plant Cell Environ. 20, 1534-1542. doi: 10.1046/j.1365-3040.1997.d01-44.x

Spokevicius, A. V., Southerton, S. G., MacMillan, C. P., Qiu, D., Gan, S., Tibbits, J. F. G., et al. (2007). $\beta$-Tubulin affects cellulose microfibril orientation in plant secondary fibre cell walls. Plant J. 51, 717-726. doi: 10.1111/j.1365313X.2007.03176.x

Tran, T. A., and Popova, L. P. (2013). Functions and toxicity of cadmium in plants: recent advances and future prospects. Turk. J. Bot. 37, 1-13.

Vélez-Bermúdez, I. C., and Schmidt, W. (2014). The conundrum of discordant protein and mRNA expression. Are plants special? Front. Plant. Sci. 5:619. doi: $10.3389 /$ fpls.2014.00619

Verhey, K. J., and Gaertig, J. (2007). The tubulin code. Cell Cycle 6, 2152-2160. doi: 10.4161/cc.6.17.4633

Vitha, S., Baluška, F., Jasik, J., Volkmann, D., and Barlow, P. (2000). "Steedman's Wax for F-actin visualization," in Actin: A dynamic Framework forMultiple Plant Cell Functions, eds C. J. Staiger, F. Baluška, D. Volkmann, and P. Barlow (Dordrecht: Kluwer Academic Publishers), 619-636.

Wallin, M., and Hartley-Asp, B. (1993). Effects of potential aneuploidy inducing agents on microtubule assembly in vitro. Mutat. Res. Fund. Mol. Mech. Mut. 287, 17-22. doi: 10.1016/0027-5107(93)90141-2

Wang, W., Vignani, R., Scali, M., Sensi, E., and Cresti, M. (2004). Post-translational modifications of $\alpha$-tubulin in Zea mays L. are highly tissue specific. Planta 218 , 460-465. doi: 10.1007/s00425-003-1122-4

Webster, D. R., and Borisy, G. G. (1989). Microtubules are acetylated in domains that turn over slowly. J. Cell Sci. 92, 57-65.

Webster, D. R., Gundersen, G. G., Bulinski, J. C., and Borisy, G. G. (1987). Differential turnover of tyrosinated and detyrosinated microtubules. Proc. Natl. Acad. Sci. U.S.A. 84, 9040-9044. doi: 10.1073/pnas.84.24.9040

Wilkins, D. A. (1957). A technique for the measurement of lead tolerance in plants. Nature 180, 37-38. doi: 10.1038/180037b0

$\mathrm{Xu}, \mathrm{P}$., Liu, D., and Jiang, W. (2009). Cadmium effects on the organization of microtubular cytoskeleton in interphase and mitotic cells of Allium sativum. Biol. Plant. 53, 387-390. doi: 10.1007/s10535-009-0073-4

Zhao, S., and Fernald, R. D. (2005). Comprehensive algorithm for quantitative real-time polymerase chain reaction. J. Comput. Biol. 12, 1047-1064. doi: $10.1089 / \mathrm{cmb} .2005 .12 .1047$

Conflict of Interest Statement: The authors declare that the research was conducted in the absence of any commercial or financial relationships that could be construed as a potential conflict of interest.

Copyright (C) 2015 Gzyl, Chmielowska-Bąk, Przymusiński and Gwóźdź. This is an open-access article distributed under the terms of the Creative Commons Attribution License (CC BY). The use, distribution or reproduction in other forums is permitted, provided the original author(s) or licensor are credited and that the original publication in this journal is cited, in accordance with accepted academic practice. No use, distribution or reproduction is permitted which does not comply with these terms. 